\title{
A unique case of embolic myocardial infarction in a 22-year-old woman with Fontan circulation
}

\author{
Marianna Vachalcováa, Marta Jakubováb, Martin Czernyc, Alžbeta \\ Bánovčinovád, Silvia Mišíkováb, Allan Böhme, Karolina Angela Sieradzkaf, \\ Pavol Török' , Gabriel Valočika ${ }^{a}$ Ingrid Schusterováf
}

a Department of Cardiology, East-Slovak Institute of Cardiovascular Diseases, Košice, Slovak Republic

${ }^{b}$ Department of Arrhythmias, East-Slovak Insititute of Cardiovascular Diseases, Košice, Slovak Republic

' Department of Cardiovascular Surgery, University Heart Center Freiburg-Bad Krozingen, Freiburg, Germany

' Department of Paediatrics and Adolescent Medicine, Faculty of Medicine, Pavol Jozef Safarik University in Košice, Slovak Republic

e National Institute of Cardiovascular Diseases, Bratislava, Slovak Republic

${ }^{f}$ Department of Functional Diagnostics, East-Slovak Institute of Cardiovascular Diseases, Košice, Slovak Republic

${ }^{g}$ Clinic of Anesthesiology, East-Slovak Institute of Cardiovascular Diseases, Košice, Slovak Republic

\section{ARTICLE INFO}

Article history:

Submitted: 21. 11. 2020

Revised: 15. 12. 2020

Accepted: 16. 12. 2020

Available online: 29. 6. 2021

Klúčové slová:

Antikoagulačná liečba

Fontanovská cirkulácia

Infarkt myokardu

Trombembolická príhoda

\section{SÚHRN}

Embólia koronárnych artérií je menej častou príčinou akútneho infarktu myokardu. Predstavujeme kazuistiku 22-ročnej pacientky s dvojvtokovou lavou komorou, defektom komorového septa a pulmonálnou stenózou po Fontanovej operácii s akútnym spodným STEMI na embolickom podklade. Okrem známych rizík vedúcich $\mathrm{k}$ trombotickým komplikáciám spojeným s Fontanovskou cirkuláciou, medzi potenciálne predisponujúce faktory trombembolizmu u tejto pacientky patrili vytvorenie trombu v dolnej dutej žile a nedostatočná antikoagulačná liečba. Táto kazuistika predstavuje jednu z prvých dokumentovaných embolických pričin STEMI u pacienta s Fontanovskou cirkuláciou. Doteraz nie je vytvorený konsenzus, že antikoagulačná terapia warfarínom je u pacientov s Fontanovskou cirkuláciou superiórna voči aspirínu v primárnej prevenci trombembolických príhod.

(c) 2021, ČKS
Keywords:

Anticoagulation therapy

Fontan circulation

Myocardial infarction

Trombembolic event

\section{ABSTRACT}

Coronary artery embolism is an uncommon cause of acute myocardial infarction. We present a case of a 22-year-old patient with double inlet left ventricle (DILV), ventricular septal defect and pulmonary stenosis after Fontan repair with an acute embolic inferior ST-segment elevation myocardial infarction (STEMI). Apart from already known risk factors of thrombotic complications associated with Fontan circulation, additional predispositions in this patient included thrombus formation located in the inferior vena cava and the lack of anticoagulation therapy. This is one of the first reported embolic causes of STEMI in a patient with a Fontan circulation. Up to date, there is no consensus that anticoagulation therapy with warfarin is superior to aspirin in primary prevention of thromboembolism in patients with Fontan circulation.

Address: MUDr. Marta Jakubová, PhD., Department of Arrhythmias, East-Slovak Institute of Cardiovascular Diseases, Ondavská 8, 04011 Košice, Slovak Republic, e-mail: mjakubova@vusch.sk DOI: $10.33678 /$ cor.2020.116 


\section{Introduction}

Fontan circulation is associated with a higher risk of thromboembolic events. However, the incidence of embolic myocardial infarction (MI) is very rare. We represent a unique case of a young patient after fenestrated Fontan repair, presenting with embolic inferior STEMI. The antithrombotic treatment strategy plays a pivotal role in primary and secondary prevention of thromboembolism.

\section{Case report}

We report a case of a 22-year-old woman with double inlet left ventricle, pulmonary stenosis, and ventricular septal defect who underwent superior cavo-pulmonary shunt (Glenn) at the age of one year and atrio-pulmonary (Fontan) connection at the age of 4 years. Recurrent supraventricular tachycardia necessitated multiple electrophysiological studies, which led to ablation of the posteroseptal accessory pathway at the age of 11 years.

In 2017, she referred to the emergency department for acute chest pain radiating to the neck. Examination showed no signs of heart failure, blood pressure was 100/60 $\mathrm{mmHg}$. The ECG showed significant ST segment elevations in limb leads II, III and aVF (Fig. 1).

A transthoracic echocardiogram (TTE) revealed preserved left ventricular ejection fraction (LVEF 50\%), hypokinesis of inferior wall, trivial mitral and tricuspidal regurgitation, suspicion of thrombus formation of width $5 \mathrm{~mm}$ and length $38 \mathrm{~mm}$ in inferior vena cava (IVC) (Figs 2, 3). Her chronic medical therapy included sotalol ( $2 \times 80 \mathrm{mg})$ and acetylsalicylic acid (1× $100 \mathrm{mg})$. She was transported to the East Slovak Institute of Cardiovascu- lar Diseases and was medicated according to the STEMI guidelines with heparin and dual antiplatelet therapy. Her creatine kinase peaked to $5.72 \mu \mathrm{kat} / \mathrm{l}$, MB fraction of creatine kinase peaked to 0.46 , high sensitive troponin $\mathrm{T}$ (hsTn-T) peaked to $0,390 \mu \mathrm{g} / \mathrm{l}$. NT-proB-type natriuretic peptide was $137,8 \mathrm{pg} / \mathrm{ml}$ and D-dimers $0,36 \mathrm{mg} / \mathrm{l}$. The complete blood count was normal. The patient's symptoms, TTE findings with regional wall motions abnormalities and elevation of hsTn-T over 99 percentile were consistent with the definition of acute STEMI. Selective coronary angiography showed normal findings. No coronary artery anomalies were detected (Fig. 4) which raised the possibility of spasm or thromboembolism. Serial electrocardiograms showed the typical changes of acute myocardial infarction (Fig. 5).

Ultrasonographic examination of lower extremities ruled out the possibility of deep venous thrombosis. Cardiac magnetic resonance imaging (CMR) was performed and revealed a patent Fontan pathway, however no thrombus was detected and the pulmonary arborization was normal. The left ventricular ejection fraction was $50 \%$, but the late gadolinium enhancement showed post-ischemic changes after transmural myocardial infarction of the inferior wall (Fig. 6). The patient had a complete hematological examination, which excluded thrombophilia. Recommended therapy on discharge was: acetylsalicylic acid $100 \mathrm{mg}$, clopidogrel $75 \mathrm{mg}$, proton pump inhibitor $20 \mathrm{mg}$, sotalol $2 \times 80 \mathrm{mg}$, cardilan 175 $\mathrm{mg}$ and atorvastatin $80 \mathrm{mg}$. Because of the second type of $\mathrm{MI}$ and the thrombus formation in IVC documented during the first TTE, antithrombotic therapy was changed in outpatient care for warfarin. During the three years of follow-up, the patient has no signs of thrombotic recurrence.

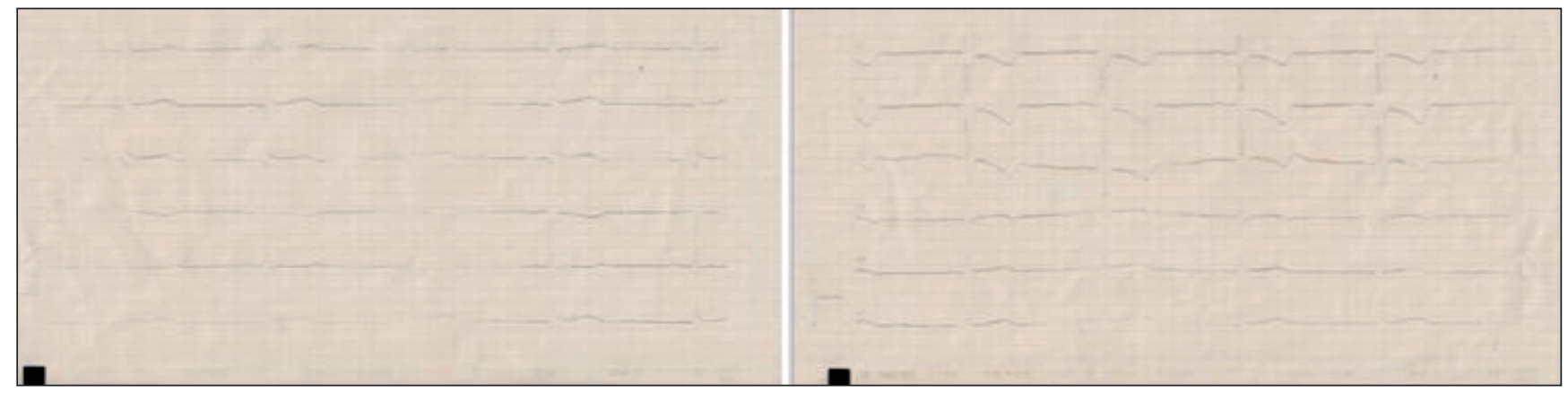

Fig. 1 - ECG showed signs of inferior STEMI.

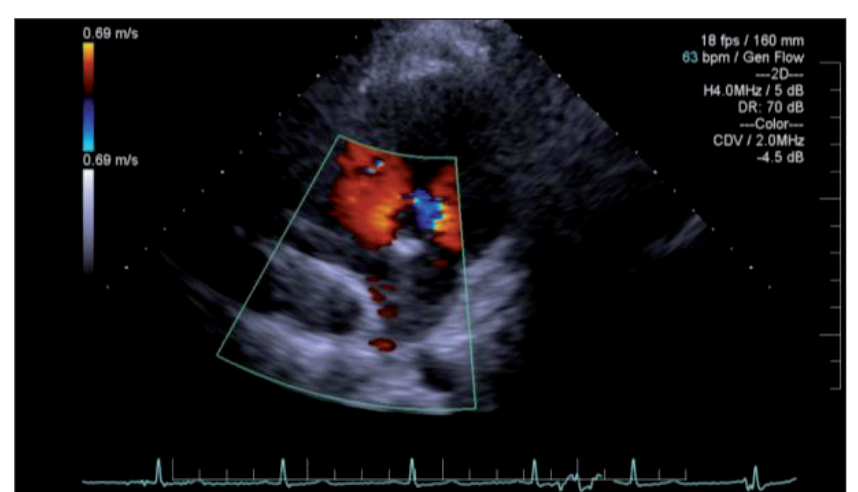

Fig. 2 - Echocardiography - four-chamber view.

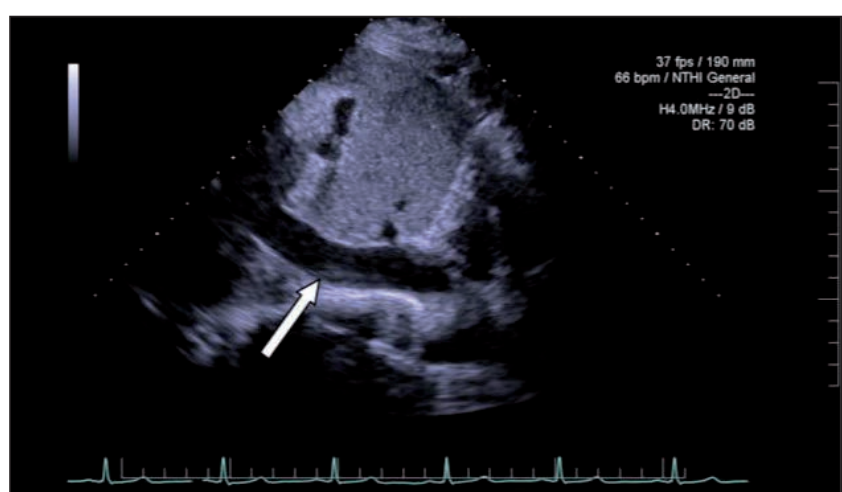

Fig. 3 - Echocardiography - thrombus formation located in inferior vena cava. 

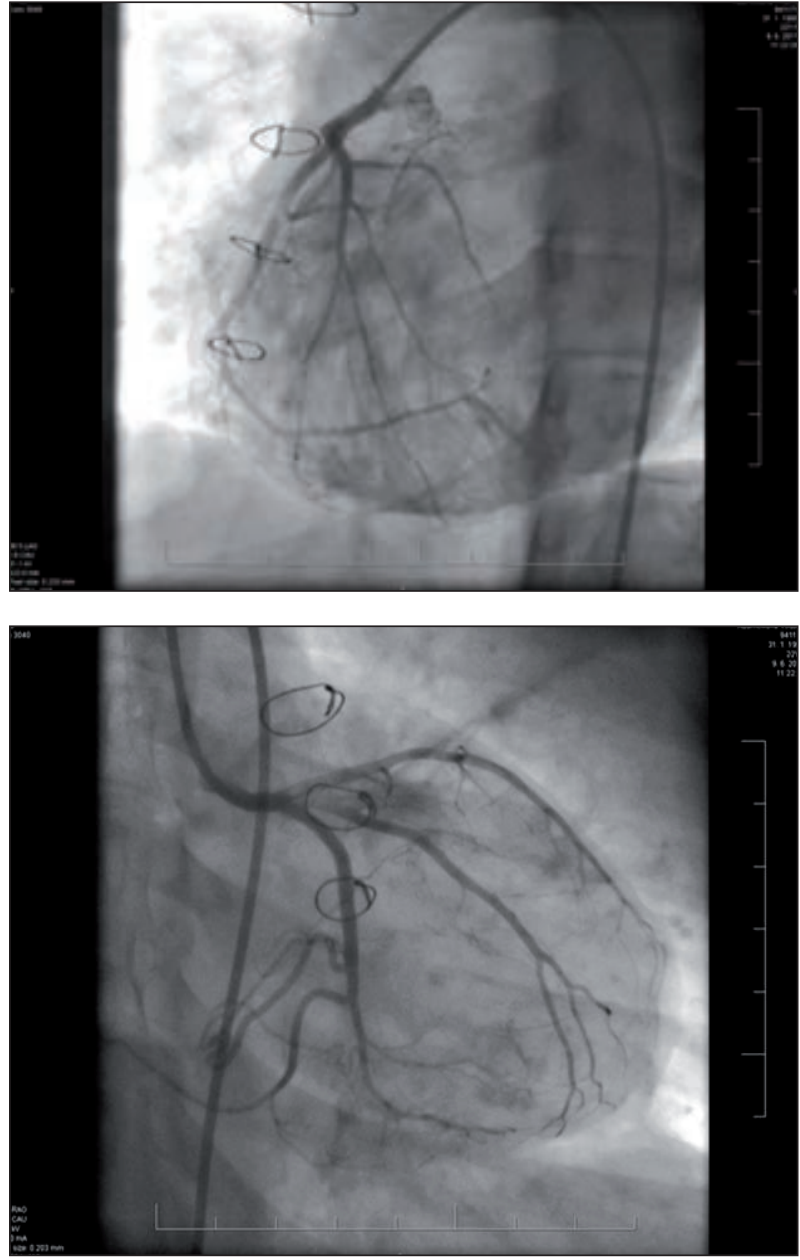

Fig. 4 - Selective coronary angiography - normal finding.

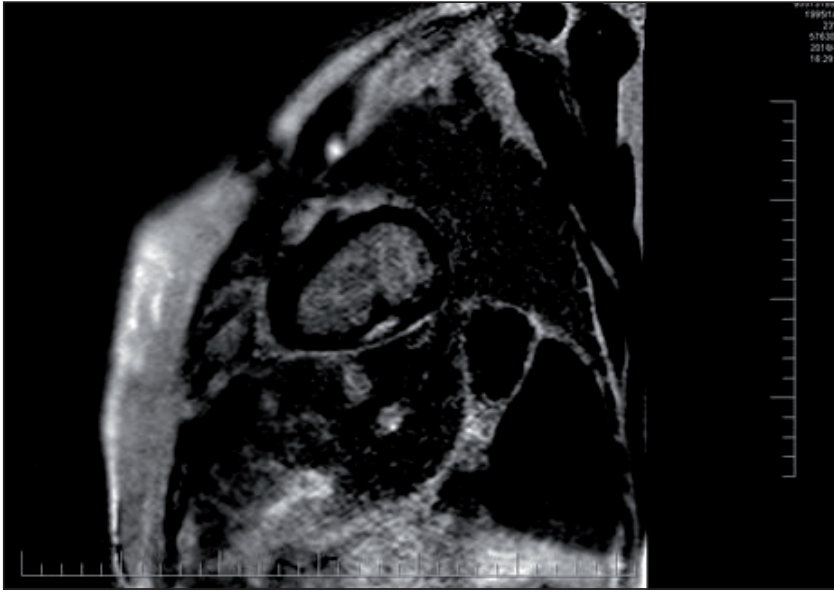

Fig. 6 - Cardiac magnetic resonance imaging (MRI), the late gadolinium enhancement showed the signs of past inferior transmural ischemia.

circulation are surviving into adulthood. However, due to the abnormal circulation, they have an increased risk of complications. The frequent late complications are arrhythmias, thromboembolism, protein-losing enteropathy, heart failure and plastic bronchitis. ${ }^{3,4}$

The most common etiological factors of thromboembolism are endothelial dysfunction, abnormal blood flow, hypercoagulability, presence of a right-to-left shunt. ${ }^{5}$ The recognised locations of thrombus embolisation are caval veins, right atrium, pulmonary artery, venous chamber and cerebral arteries. ${ }^{6} \mathrm{Ml}$ due to embolic occlusion of coronary arteries post-Fontan surgery is very rare and was described only in a few patients; with repaired hypoplastic left heart syndrome, with history of double outlet right

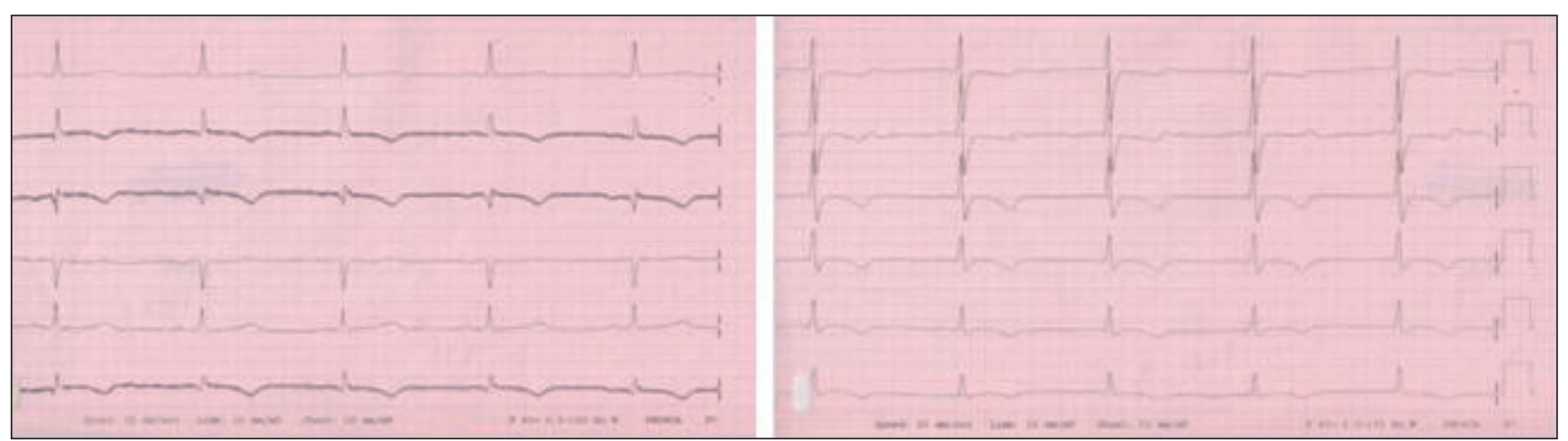

Fig. 5 - ECG after selective coronary angiography.

\section{Discussion}

The Fontan procedure was first performed in 1968 in a patient with tricuspid atresia and has transformed the lives of children born with single-ventricle physiology. ${ }^{1}$ The earlier Fontan connected the right atrial appendage to the pulmonary artery (PA). The current procedure is an extracardiac conduit going from the inferior vena cava to the PA, and a Glenn connection joining the superior vena cava to the right PA. ${ }^{2}$ Most of patients with Fontan ventricle, with ventricular septal defect, with pulmonary atresia and severe right heart hypoplasia who underwent extra-cardiac Fontan operation. Table 1 shows a summary of published case reports dealing with this topic.

We present a unique case of inferior embolic STEMI in a 22-year-old patient with fenestrated Fontan circulation due to double inlet left ventricle, ventricular septal defect and pulmonary stenosis. The potential source of embolism was the thrombus formation located in the IVC. We suppose that after the heparin and dual antiplatelet treatment in the acute phase of $\mathrm{MI}$, the coronary 
Table 1 - Summary of case report's findings of embolic MI incidence after Fontan procedure

\begin{tabular}{|l|l|l|l|l|l|}
\hline Author & Basic diagnosis before FP & Type of MI & $\begin{array}{l}\text { Age in } \\
\text { admission }\end{array}$ & $\begin{array}{l}\text { Antitrombotic treatment } \\
\text { used before admission/ } \\
\text { after discharge }\end{array}$ & $\begin{array}{l}\text { Recurrence of } \\
\text { trombembolic } \\
\text { event reported }\end{array}$ \\
\hline Hastings et al. ${ }^{14}$ & $\begin{array}{l}\text { Pulmonary atresia, severe right } \\
\text { heart hypoplasia }\end{array}$ & Inferior STEMI & 19 yo & $\begin{array}{l}\text { Aspirin/Combined aspirin } \\
\text { and warfarin therapy }\end{array}$ & No \\
\hline Deshpande et al. ${ }^{15}$ & $\begin{array}{l}\text { Tricuspid atresia, coarctation of } \\
\text { the aorta, single ventricle }\end{array}$ & $\begin{array}{l}\text { Anterolateral } \\
\text { STEMI }\end{array}$ & 17 yo & NA/NA & NA \\
\hline Subahi et al. ${ }^{16}$ & Hypoplastic left heart syndrome & $\begin{array}{l}\text { Anterolateral } \\
\text { STEMl/the only } \\
\text { one with stent } \\
\text { implantation }\end{array}$ & 10 yo & Aspirin/aspirin, clopido- \\
grel and warfarin
\end{tabular}

MI - myocardial infarction; FP - Fontan procedure; NA - not available; STEMI - ST segment elevation myocardial infarction; yo - years old.

bed was without any residual thrombotic occlusions. Moreover, MRI and ultrasound examinations did not confirm any residual vascular or intracardiac thrombus formation. However, late gadolinium enhancement showed post-ischemic signs of inferior transmural MI. The thrombus formation could have been caused by the sluggish circulation and stagnation as a result of the absence of the right ventricular pump. Alterations of coagulant factors are also one of the explanations, but the hematological examination did not reveal any anomaly. To date, however, there has been no reported difference in the incidence of thrombotic events between fenestrated and non-fenestrated Fontan circuits in recent trials. ${ }^{7}$ Based on the patient's medical records obtained from her pediatrician, she underwent indicated fenestrated Fontan procedure. Fenestration of Fontan circuit decreases postoperative morbidity and mortality rates in high-risk patients. It appears to result in a lower incidence of arrhythmia. Moreover, baffle fenestration performed at the time of Fontan surgery improves short-term outcomes in standard-risk patients by decreasing pleural drainage, length of hospital stay, and need for additional postoperative procedure. ${ }^{8,9}$ The closure of Fontan fenestration was not indicated. A persistent fenestration may be a benefit, as lower central venous pressure may decrease the risk of exercise intolerance, protein losing enteropathy, plastic bronchitis and bradyarrhythmias. In previous publications, fenestration closure was not associated with higher event-free survival. ${ }^{10}$

The thromboprophylaxis after Fontan repair is very important to prevent thromboembolism. ${ }^{11} \mathrm{Up}$ to date, there was no significant evidence proving that anticoagulation with warfarin is superior to aspirin preventing thromboembolic events in patients with Fontan circulation. ${ }^{12,13}$ However, in our case, there was thrombus formation, while on antiaggregation monotherapy with aspirin. Therefore, the treatment with warfarin was started and during a period of three years of anticoagulation therapy, there was no evidence of any thrombotic recurrence. Anticoagulation monotherapy was chosen instead of simultaneous treatment with warfarin and aspirin used in previous reported cases, because of the higher risk of bleeding. In case of future recurrence of thromboembolism despite adequate antithrombotic treatment, the consideration of fenestration closure may be needed in secondary prevention of other embolic episodes. Specific fenestration management guidelines might help in future decision making.

\section{Conclusion}

The main goal of this case report is to highlight the potential need of anticoagulation therapy instead of antiplatelet treatment in primary and secondary prevention of thromboembolic complications after Fontan repair. There is a need for a large multicentered randomized control trials comparing the two treatment strategies and focusing on the perspective of new oral anticoagulants. Secondary, we want to emphasize, that acute Ml of embolic origin is one of the very rare and life threatening complications of Fontan circulation, even in very young patients, regardless of the primary diagnosis requiring Fontan operation in childhood.

\section{Conflict of interest}

Authors declare no conflict of interests.

\section{Funding}

This article was not supported by any grant.

\section{References}

1. Bezuska L, Lebetkevicius V, Sudikiene R, et al., 30-year experience of Fontan surgery: single-centre's data. J Cardiothorac Surg 2017;12:67. 
2. Stout KK, Daniels CJ, Aboulhosn JA, et al. 2018 AHA/ACC Guideline for the Management of Adults With Congenital Heart Disease: A Report of the American College of Cardiology/American Heart Association Task Force on Clinical Practice Guidelines. J Am Coll Cardiol 2019;73:e81.

3. Frigiola A, Lo Rito M. Late complications of Fontan operation. G Ital Cardiol (Rome) 2017;18:625-630.

4. Dennis M, Zannino D, du Plessis K, et al. Clinical outcomes in adolescents and adults after the Fontan procedure. J Am Coll Cardiol 2018;71:1009-1017.

5. Attard C, Huang J, Monagle P, et al. Pathophysiology of thrombosis and anticoagulation post Fontan surgery. Thromb Res 2018;172:204-213.

6. Deshaies C, Hamilton RM, Shohoudi A, et al. Alliance for Adult Research in Congenital Cardiology (AARCC). Thromboembolic Risk After Atriopulmonary, Lateral Tunnel, and Extracardiac Conduit Fontan Surgery. J Am Coll Cardiol 2019;74:1071-1081.

7. McCrindle BW, Manlhiot $C$, Cochrane A, et al. Factors associated with thrombotic complications after the Fontan procedure: A secondary analysis of a multicenter, randomized trial of primary thromboprophylaxis for 2 years after the Fontan procedure. J Am Coll Cardiol 2013;61:346-353.

8. Lamler MS, Scott WA, Leonard SR, et al. Fenestration improves clinical outcome of Fontan procedure. A prospective randomized study. Circulation 2002;105:207-212.

9. Li D, Li M, Zhou X, et al. Comparison of the fenestrated and non-fenestrated Fontan procedures: A meta-analysis. Medicine (Baltimore) 2019;98:e16554.

10. Imielski BR, Woods RK, Mussatto KA, et al. Fontan fenestration closure and event-free survival. J Thorac Cardiovasc Surg 2013;145:183-187.

11. Potter $B J$, Leong-Sit $P$, Fernandes $S M$, et al. Effect of aspirin and warfarin therapy on thromboembolic events in patients with univentricular hearts and Fontan palliation. Int J Cardiol 2013;168:3940-3943.

12. Viswanathan $\mathrm{S}$. Thromboembolism and anticoagulation after Fontan surgery. Ann Pediatr Cardiol 2016;9:236-240.

13. Al-Jazairi AS, Al Alshaykh HA, Di Salvo G, et al. Assessment of Late thromboembolic Complications Post-Fontan Procedure in Relation to Different antithrombotic Regimens: 30-Years' Follow-up Experience. Ann Pharmacother 2019;53:786-793.

14. Hastings RS, McElhinney DB, Saric M, et al. Embolic myocardial infarction in a patient with a Fontan circulation. World J Pediatr Congenit Heart Surg 2014;5:631-634.

15. Deshpande SR, Dalal A, Kim DW, et al. Acute Embolic Myocardial Infarction and Heart Failure in a Fontan Patient: Recovery with Impella Device and Successful Transplantation. ASAIO J 2016;62:e52-e54.

16. Subahi A, Forbes $T$, Ali OE. Percutaneous coronary intervention following Fontan procedure. Int J Cardiol Heart Vasc 2020;28:100511.

17. Shamoon R, Habib H, Rampal U, et al. A Rare Case of Embolic ST-Elevation Myocardial Infarction in an Adult Patient With Repaired Hypoplastic Left Heart Syndrome. World J Pediatr Congenit Heart Surg 2017;8:543-549.

18. Noonan PM, Taliotis D, Alahmar A. Percutaneous coronary intervention in a 3/year/old with hypoplastic left heart syndrome. Catheter Cardiovasc Interv 2015;85:1209-1211.

19. Wilson DG, Wisheart JD, Stuart AG. Systemic thromboembolism leading to myocardial infarction and stroke after fenestrated total cavopulmonary connection. Br Heart $J$ 1995;73:483-485

20. Meier LM, Van De Bruaene A, Charla P, et al. Transmural circumflex infarction in a young Fontan patient: to leave home to find it. Eur Heart J Cardiovasc Imaging 2018;19:953954. 